\title{
Evaluation of Preparedness Towards Total Quality Management at Tertiary Hospital from Health Workers Perception: A Case Study
}

\author{
Obi Ikechukwu Vincent ${ }^{1,}$, , Okoronkwo Ijeoma Lewechi², Akubue Augustine Uchenna ${ }^{3}$, \\ Ughasoro Maduka ${ }^{4}$, Akubue Ngozika Peace ${ }^{5}$, Uche Glory Igbo ${ }^{5}$, Nnanke Etimita ${ }^{6}$, Emeka Onugu $^{7}$, \\ Emmanuel Shekarau $^{8}$, Abonyi Isaiah Chimezie ${ }^{9}$, Chine Paul Udoka ${ }^{10}$, Joseph Akem Ingwu ${ }^{11}$ \\ ${ }^{1}$ Department of Health Management and Administration, University of Nigeria, Enugu, Nigeria \\ ${ }^{2}$ Department of Nursing Services, University of Nigeria, Enugu, Nigeria \\ ${ }^{3}$ Department of Environmental Health, Nnamdi Azikiwe University, Nnewi, Nigeria \\ ${ }^{4}$ Department of Paediatrics, University of Nigeria, Enugu, Nigeria \\ ${ }^{5}$ Health Education Department, Healthline Consulting Limited, Enugu, Nigeria \\ ${ }^{6}$ Department of M\&E, Breakthrough Action, Calabar, Nigeria \\ ${ }^{7}$ Monitoring and Evaluation Units, Catholic Relief Services, Abuja, Nigeria \\ ${ }^{8}$ Case Management Unit, National Malaria Elimination Programme, Abuja, Nigeria \\ ${ }^{9}$ Department of Environmental Health Science, Nnamdi Azikiwe University, Nnewi, Nigeria \\ ${ }^{10}$ ICT department, UNICEF, Enugu, Nigeria \\ ${ }^{11}$ Department of Public Health, Ministry of Health, Calabar, Nigeria
}

Email address:

ivcobi@yahoo.com (O. I. Vincent)

${ }^{*}$ Corresponding author

\section{To cite this article:}

Obi Ikechukwu Vincent, Okoronkwo Ijeoma Lewechi, Akubue Augustine Uchenna, Ughasoro Maduka, Akubue Ngozika Peace, Uche Glory Igbo, Nnanke Etimita, Emeka Onugu, Emmanuel Shekarau, Abonyi Isaiah Chimezie, Chine Paul Udoka, Joseph Akem Ingwu. Evaluation of Preparedness Towards Total Quality Management at Tertiary Hospital from Health Workers Perception: A Case Study. European Journal of Preventive Medicine. Vol. 7, No. 2, 2019, pp. 40-49. doi: 10.11648/j.ejpm.20190702.12

Received: April 24, 2019; Accepted: June 3, 2019; Published: June 12, 2019

\begin{abstract}
Background: Total quality management (TQM) in any organization is a major determinant of efficient management of resources. In this era where hospitals provide the same type of services, it is only hospitals that have embraced TQM techniques that will survive. The study assessed the management preparedness to the implementation of TQM at University of Nigeria Teaching Hospital (UNTH) Ituku/ Ozalla from the Health workers perceptive. Methods: This study was a cross sectional descriptive study. Structured questionnaire was used to collect information on the demographic characteristics of the randomly selected staff of the UNTH and their assessment of UNTH under five major domains: organizational, interpersonal, facilities, environmental and economic. Focus group discussion was also used conducted among selected staff. Results: On influence of educational factors on level of response, the study showed it has no influence on staff awareness ( $\mathrm{p}=$ $0.264)$ but it influenced quality of personnel (0.049), sufficient supervision $(p=0.039)$, feedback mechanism $(p=0.005)$ and record department being computerized $(p=0.04)$. Number of years on the job has influence on the availability of adequate resources $(p=0.027)$, quality of services $(0.040)$ and record department being computerized $(p=0.041)$. On the influence of cadre, it showed that level of awareness was affected but quality of personnel $(p=0.014)$, quality of services $(p=0.019)$ and availability of functional diagnostic equipment $(p=0.027)$ was influenced. Conclusions: TQM have been shown to have improved the efficient management of resources with attendant maximization of output. It is important that management demonstrates commitment and provide enabling environment for its sustainability. Specifically, management should institute periodic performance measurement system and strengthen the training program in the hospital. There is a need to raise the awareness on the concept and develop methods and procedures in updating existing TQM guidelines.
\end{abstract}


Keywords: Total Quality Management, University of Nigeria Teaching Hospital, Health Workers, Perception

\section{Introduction}

Presently in the world, the changes and development occurring in both service and manufacturing sectors of the economies have resulted to a challenging and increasing competitive environment for them. This competition mirrors on both pre and post service delivery instead of products attributes and its production $[1,36]$. This obvious growth in the service sector of the economy is also expected to be followed by increase in the product marketing and management skill as well $[2,3]$. This growth is likely to affect internal workings and operations of organizations (e.g internal efficiency leading to increased productivity of labor and profits) and then to the external operations of these organizations (e.g consumer behavior leading to customer satisfaction and loyalty); and finally a shift from a focus on organizational structure to a focus that will be on process [4, 5].

This shift in direction in the conceptual thinking on better ways of service marketing and organizational management has led to researches in quality of service delivery. Quality of service provision is not just a very important factor for consumer satisfaction, but it is also the principal indicator that shows how competitive a service organization can be measured $[6,7]$. In order to achieve this service excellence, hospitals must strive for zero defects in their operations, to keeping every customer that the company can profitably and comfortably serve. Zero defects therefore require that organizations continuously channel their efforts towards improving quality of the service delivery to their customers $[8,9]$.

In Nigeria, the management of public healthcare system is filled with intractable problems that need holistic approach to its management $[10,11]$. There is the shortage of manpower requirement in public health sector because of the unattractiveness of the salary resulting in a low Doctorpatient ratio when compared to World Health Organization Standard of one Doctor to 2,500 patients $[10,11]$. The poor state of the healthcare delivery system is reflected in the declining standards and facilities at the Federal, State and Local Government Level [11]. The services provided at these public health facilities are generally perceived by members of the public as being very poor $[12,7]$. The type of ill treatment often experienced by patients is a source of discouragement to them from patronizing public healthcare providers $[13,7]$. This hostile attitude of hospital employees has created a boom in the market for private hospitals and alternative medicine with the attendant dangers.

Other problems faced by patients who access public health facilities are overcrowding, delay in consultation with the Doctors and lack of proper guidance by the hospital staff. The need to improve healthcare services that are provided in Public hospitals in Nigeria is imperative now because the competition in the healthcare industry is growing in Nigeria and this is occasioned by the licensing of many hospitals in the country $[14,15]$.

As with every good product, the services of a good hospital services market it. This word of mouth marketing comes mostly from people who have experienced the services in the hospital. However, a good product or service cannot by itself, project hospital services to the users. Certain mechanism should be put in place to achieve this purpose $[12,15]$. Here, in Nigeria hospital advertisement is strictly prohibited by the Nigeria Medical Association. Services in public health institutions are still poor despite recent introduction of service compact with all Nigerians (SERVICOM) by the Nigerian Government for improving service delivery in the public health institutions. Periodic patient satisfaction surveys that should routinely be carried out to ascertain the satisfaction level of the patients are not done $[16,37]$.

Importantly, TQM is therefore seen as being a key factor in determining the success and survival of hospitals in today's competitive business environment [17]. Any dissatisfaction by the customer due to poor service quality delivery would be a serious concern to the management of any organization. Similarly, consumers are becoming increasingly aware of rising standards in service quality which is a resultant effect of the stiff competitions which have developed among hospitals [18]. A total quality management system in healthcare is then perceived as a structured organizational operation that involves the staff of that organization at different levels of planning, measuring and assessing patient care in such a way as to provide the best clinical services to their patients [19].

This is a management principle which public health institutions should adopt as a fundamental business strategy because it is a concept that involves continuous improvement. No organization can afford to be competitive if it does not continuously improve on its product/services, processes and people. There is therefore an urgent need for an organization - wide approach and commitment for quality improvement to revitalize the health system. TQM option is considered a way out for improving quality services. The questions being raised in this study are; are TQM principles being practiced in UNTH Ituku Ozalla? What is the level of management preparedness in the implementation? Are there demographic factors that might influence the responses of the respondents?

This study is very important in many respects. Public hospitals are entrusted with the provision of affordable healthcare services to the public. A programme must exist for attracting patients as well as rendering optimal service to these patients. Findings in this study will be useful in trying to see perception of workers on the overall level of implementation of total quality management by the UNTH Ituku Ozalla management and the Nigeria healthcare industry 
managers in general. Also, the study will give a picture to healthcare providers on the critical factors that enhance/hinder the implementation of the total quality management concept in healthcare industry.

\section{Methods}

\subsection{Study Design}

The study was a cross sectional descriptive study among the staff of University of Nigeria Teaching Hospital (UNTH) Ituku Ozalla.

\subsection{Study Area}

The UNTH is a tertiary hospital with different departments The hospital has a board headed by a chairman and the chief medical director directs the day-to-day management of the hospital. The different departments have head of department that reports to the CMD through the Chairman Medical Advisory Committee for medical related issues, and through the Director of Administration for non-medical related issues. The hospital has main site and other out-station clinics.

\subsection{Population of Study}

The study population was the staff of the hospital whose names appeared on the Nominal roll from the personnel department. At the time of the study, a total staff population of 3346 was recognized staff of the hospital (personnel department).

The final minimum sample size of 346 was obtained in two staged. First the initial sample of 384 was obtained using EpiInfo computing the prevalence of $50 \%$ (assumed since no previous study has been conducted), $95 \%$ confidence interval and power of $80 \%$. However, since the population of UNTH staff is less than 10,000 . The final sample size estimated using the formula:

$$
f=\frac{n o}{1+n o / N}
$$

Where: $\mathrm{nf}=$ desired sample size when the population is less than 10,000 , no $=$ sample size of 384 , obtained if the population is more than 10,000, $\mathrm{N}=$ Estimate of the population size of 3346 . Therefore, when input into the above formula, the final sample size of 346 .

\subsection{Sampling Procedure}

The 3346 staff of UNTH from different department was stratified into high (696), middle (1450) and low (1200) cadre. The proportions of each cadre to be sampled were high (72), middle (150) and low (124) cadre. Staff who gave written consent to participate in the study was surveyed.

\subsection{Data Collection}

Structured questionnaire was used to collect demographic data of the respondents. The respondents were allowed to choose the option that best suits their assessment of each of the tested TQM domains using Likert scales. Also Focus Group Discussion (FGD) was conducted among the key stakeholders. The FGD were held with health workers in seven (7) purposively selected disciplines in the hospital who have direct access to patients that accesses care in the hospital (Nursing, Pharmacy, Doctors, Laboratory scientists, Administration staff, Dieticians and Physiotherapist). The Focus group discussion (FGD) members were categorized into different cadres (high, middle, low). Three FGD members were purposively selected from each of the seven purposively selected disciplines making it a total of twenty one (21) FGD members. A total of three FGD sessions was conducted, one for each of the three cadres (high, middle, low).

\subsection{Ethical Consideration}

The ethics committee of UNTH Ituku Ozalla gave approval for this study. Written Informed consent was obtained from each respondent before participating in the study.

\subsection{Data Analysis}

Data entry was done with epi info version 3.5.2 and subsequently the data was analyzed with SPSS version 18 . Quantitative data - During the analysis, a lot of coding and grouping were done for ease of analysis. The respondent's ages were grouped into four categories viz: 15-25yrs, 26$36 \mathrm{yrs}, 37-47 \mathrm{yrs}$ and $48-60 \mathrm{yrs}$ for the generation of frequency table. The respondents' level of education was grouped into two categories (pre-tertiary and tertiary). Years respondent were on the job was also recoded into less than 10 and greater than or equal to 10 years.

The traditional even numbered Likert scale was used for each domain: strongly agreed, agreed, disagreed and strongly disagreed, but later binomial responses were obtained by grouping (strongly agreed and agreed) as one and disagreed and strongly agreed as another. A chi-square was used to test for significant and p-value $<0.05$ was significant.

Qualitative data - The records of the FDGs from the tape recorder were transcribed. Axial coding system was used and the emerging theme/categories were developed by reading the transcript severally in order to establish the relationship between the codes/ labels and the emerging themes.

The thematic analysis was used to understand common experiences from the responses and also to understand the agreements and disagreements arising from the participants narratives in each study site. NVivo software (version 8) was used to analyze the data

\section{Results}

Out of the three hundred and eighty (380) questionnaires administered, three hundred and forty nine (349) were correctly filled and retrieved giving a response rate of $93.3 \%$. 


\subsection{Demographic Characteristics of Respondents}

Table 1. Demographic characteristics of respondents.

\begin{tabular}{|c|c|c|}
\hline Demographic characteristics & Frequency $n=349$ & Percentage \\
\hline \multicolumn{3}{|l|}{ Gender } \\
\hline Female & 152 & 43.6 \\
\hline Male & 197 & 56.4 \\
\hline \multicolumn{3}{|l|}{ Age group } \\
\hline $15-25 y r s$ & 64 & 18.3 \\
\hline $26-36 \mathrm{yrs}$ & 84 & 24.1 \\
\hline $37-47 \mathrm{yrs}$ & 90 & 25.8 \\
\hline $48-60 y r s$ & 111 & 31.8 \\
\hline \multicolumn{3}{|l|}{ Religion } \\
\hline Christian & 265 & 75.9 \\
\hline Islam & 15 & 4.3 \\
\hline Traditional/others & 69 & 19.8 \\
\hline \multicolumn{3}{|l|}{ Level of Education } \\
\hline Primary & 37 & 10.6 \\
\hline Secondary & 115 & 33 \\
\hline University & 157 & 45 \\
\hline Others & 40 & 11.5 \\
\hline \multicolumn{3}{|l|}{ Present marital status } \\
\hline Single & 129 & 37 \\
\hline Married & 145 & 41.5 \\
\hline Separated/Divorced/Widowed & 75 & 21.5 \\
\hline \multicolumn{3}{|l|}{ Ethnic group } \\
\hline Igbo & 241 & 69.1 \\
\hline Hausa & 19 & 5.4 \\
\hline Yoruba & 26 & 7.4 \\
\hline *Others & 63 & 18.1 \\
\hline \multicolumn{3}{|l|}{ Number of years on the job } \\
\hline $1-4 \mathrm{yrs}$ & 145 & 41.5 \\
\hline $5-9 \mathrm{yrs}$ & 101 & 28.9 \\
\hline$\geq 10$ & 103 & 28.5 \\
\hline \multicolumn{3}{|l|}{ Cadre/Grade level } \\
\hline High & 84 & 24.1 \\
\hline Middle & 145 & 41.5 \\
\hline Low & 120 & 34.4 \\
\hline \multicolumn{3}{|l|}{ Job specialty } \\
\hline Medical & 105 & 30.1 \\
\hline Paramedical & 72 & 20.6 \\
\hline Non-medical & 100 & 28.7 \\
\hline Others & 72 & 20.6 \\
\hline
\end{tabular}

*Others - Respondents with only on the job training, $\mathrm{P}=0.05$ 。

Table shows Mean age of respondents was 39.1 years and most $(31.4 \%, 111 / 349)$ were within the age range of 48 - 60 years. Majority $(45 \%, 157 / 349)$ attained university education. Most $(41.5 \%, 145 / 349)$ of the respondents had spent between 5 years or less on the job.

\subsection{Responses of TQM Variables}

Table 2. Responses to TQM variables.

\begin{tabular}{lll}
\hline \multirow{2}{*}{ Variables } & Frequency (Percent) & Disagree \\
\cline { 2 - 3 } & Agree & \\
Organizational factors & & $199(57.0)$ \\
Management are committed to philosophy & $150(43.0)$ & $222(63.6)$ \\
Management makes effort in training staff & $127(36.4)$ & $227(65.0)$ \\
Resources of the hospital are adequate & $122(35.0)$ & $172(49.3)$ \\
Management motivates staff adequately & $177(50.7)$ & $168(48.1)$ \\
Staff awareness is good & $181(51.9)$ & $212(60.7)$ \\
Interpersonal factors & & $238(68.2)$ \\
Mgt. are open to suggestions & $137(39.3)$ & $219(62.8)$ \\
Personnel quality are adequate & $111(31.8)$ & $197(56.4)$ \\
Sufficient supervision of staff & $130(37.2)$ & \\
Feedback mechanism is in place & $152(43.6)$ &
\end{tabular}




\begin{tabular}{|c|c|c|}
\hline \multirow{2}{*}{ Variables } & \multicolumn{2}{|c|}{ Frequency (Percent) } \\
\hline & Agree & Disagree \\
\hline Poor service delivery & $173(49.6)$ & $176(50.4)$ \\
\hline Staff attitude are not encouraging & $143(41.0)$ & $206(59.0)$ \\
\hline Poor employee attitude to work & $143(41.0)$ & $206(59.0)$ \\
\hline \multicolumn{3}{|l|}{ Facilities factors } \\
\hline State of the art equipment & $82(23.5)$ & $267(76.5)$ \\
\hline Hospital facility support TQM practice & $98(28.1)$ & $251(71.9)$ \\
\hline Pharmacy is well stocked with drugs & $83(23.8)$ & $266(76.2)$ \\
\hline Computerized record department & $134(38.4)$ & $215(61.6)$ \\
\hline Nursing service provides quality care & $132(37.8)$ & $217(62.2)$ \\
\hline Functional lab services & $150(43.0)$ & $199(57.0)$ \\
\hline Functional radiology equipment & $114(32.7)$ & $235(67.3)$ \\
\hline Location of hospital affects TQM & $108(30.9)$ & $241(69.1)$ \\
\hline \multicolumn{3}{|l|}{ Environmental factors } \\
\hline TQM standards are communicated & $80(22.9)$ & $269(77.1)$ \\
\hline Consistent updated regulations & $129(37.0)$ & $220(63.0)$ \\
\hline UNTH conforms to TQM standards & $172(49.3)$ & $177(50.7)$ \\
\hline Routine check available & $165(47.3)$ & $184(52.7)$ \\
\hline \multicolumn{3}{|l|}{ Economic factors } \\
\hline Subvention from govt. are adequate & $116(33.2)$ & $233(66.8)$ \\
\hline Adequate imprest is disbursed to run dept. & $106(30.4)$ & $243(69.6)$ \\
\hline Cost of accessing services is cheap & $123(35.2)$ & $226(64.8)$ \\
\hline
\end{tabular}

Table 2 shows the respondents assessment of the level of implementation of TQM factors in the hospital. Most disagreed on implementation of virtually all domains, except on adequacy of management motivation of staff and good staff awareness.

\subsection{Influence of Educational Level of Respondents on Perception of Implementation of TQM Factors}

Table 3. Influence of Educational level of Respondents on positive perception of implementation of TQM factors.

\begin{tabular}{|c|c|c|c|}
\hline Variable & Pre-tertiary $n=152(\%)$ & Tertiary $\mathrm{n}=197(\%)$ & p-value \\
\hline \multicolumn{4}{|l|}{ Organizational factors } \\
\hline Committed to Philosophy $(\mathrm{n}=150)$ & $104(69.3)$ & $46(30.7)$ & $0.000 *$ \\
\hline Conscious effort in training $(\mathrm{n}=127)$ & $84(66.1)$ & $43(33.3)$ & $0.000 *$ \\
\hline Adequate hospital resources $(\mathrm{n}=122)$ & $67(54.9)$ & $55(45.1)$ & $0.002 *$ \\
\hline Adequate motivation of staff $(\mathrm{n}=177)$ & $90(50.8)$ & $87(49.2)$ & $0.005 *$ \\
\hline Staff awareness $(n=181)$ & $84(46.4)$ & $97(53.6)$ & 0.264 \\
\hline \multicolumn{4}{|l|}{ Interpersonal factors } \\
\hline Open to suggestions \& ideas $(\mathrm{n}=137)$ & $66(48.2)$ & $71(51.8)$ & 0.162 \\
\hline The quality of personnel is $(\mathrm{n}=111)$ & $56(50.5)$ & $55(49.5)$ & $0.049^{*}$ \\
\hline Sufficient supervision of staff $(n=130)$ & $65(50.0)$ & $65(50.0)$ & $0.039 *$ \\
\hline A feedback mechanism in place $(\mathrm{n}=152)$ & $79(52.0)$ & $73(48.0)$ & $0.005 *$ \\
\hline Poor services $(\mathrm{n}=173)$ & 79 (45.7) & $94(54.3)$ & 0.430 \\
\hline Staff attitudes to patients are not encouraging $(n=143)$ & $62(43.4)$ & $81(56.6)$ & 0.951 \\
\hline \multicolumn{4}{|l|}{ Facility factors } \\
\hline State of the art equipment $(n=82)$ & $43(52.4)$ & $39(47.6)$ & $0.042 *$ \\
\hline Hospital facilities can support the practice of TQM $(n=98)$ & $49(50.0)$ & $49(50.0)$ & 0.081 \\
\hline Nursing service provides quality care $(\mathrm{n}=132)$ & $67(50.8)$ & $65(49.2)$ & $0.034 *$ \\
\hline Functional diagnostic equipment @ radiology department $(\mathrm{n}=114)$ & $56(49.1)$ & $58(50.9)$ & 0.089 \\
\hline
\end{tabular}

Statistically Significant $=*$ at $\mathrm{p}=0.05$.

Table 3 showed that the respondents' educational level had influence on their responses to all the organizational factors with the exception of staff awareness with $(\mathrm{p}=0.264)$, On interpersonal factors, findings showed that educational level had influence on quality of personnel $(p=0.049)$, sufficient supervision $(p=0.039)$ and feedback mechanisms $(p=0.005)$. On the other hand, educational level did not have influence on management being open to suggestions, poor services in the hospital and staff attitude to patients. On facility factors, the result showed that educational level had influence on only record department being computerized $(\mathrm{p}=0.041)$.

\subsection{Influence of Respondents' Years on the Job on Their Perception of Implementation of TQM Factors}

Table 4. Influence of years on the job of Respondents on positive perception of implementation of TQM factors.

\begin{tabular}{llr}
\hline Variables & $<$ 10yrs & p-value \\
\hline Organizational factors & & 10 yrs \\
Committed to Philosophy $(\mathrm{n}=150)$ & $105(70.0)$ & $45(30.0)$ \\
\hline
\end{tabular}




\begin{tabular}{|c|c|c|c|}
\hline Variables & $<10$ yrs & $>10 y r s$ & p-value \\
\hline Conscious effort in training $(\mathrm{n}=127)$ & $91(71.7)$ & $36(28.3)$ & 0.718 \\
\hline Adequate hospital resources $(n=122)$ & $95(77.9)$ & $27(22.1)$ & $0.027 *$ \\
\hline Adequate motivation of staff $(n=177)$ & $129(72.9)$ & $48(27.1)$ & 0.320 \\
\hline Staff awareness $(n=181)$ & $124(68.5)$ & $57(31.5)$ & 0.400 \\
\hline \multicolumn{4}{|l|}{ Interpersonal factors } \\
\hline Open to suggestions $\&$ ideas $(n=137)$ & $98(71.5)$ & $39(28.5)$ & 0.731 \\
\hline The quality of personnel is $(\mathrm{n}=111)$ & $81(73.0)$ & $30(27.0)$ & 0.487 \\
\hline A feedback mechanism in place $(\mathrm{n}=152)$ & $112(73.7)$ & $40(26.3)$ & 0.250 \\
\hline Poor services $(n=173)$ & $114(65.9)$ & $59(34.1)$ & $0.040 *$ \\
\hline Staff attitudes to patients are not encouraging $(n=143)$ & $98(68.5)$ & $45(31.5)$ & 0.505 \\
\hline \multicolumn{4}{|l|}{ Facility factors } \\
\hline State of the art equipment $(n=82)$ & $58(70.7)$ & $24(29.3)$ & 0.956 \\
\hline Hospital facilities can support the practice of TQM $(n=98)$ & $71(72.4)$ & $27(27.6)$ & 0.616 \\
\hline Nursing service provides quality care $(\mathrm{n}=132)$ & $86(64.2)$ & $48(35.8)$ & $0.041 *$ \\
\hline
\end{tabular}

Statistically Significant $=* \mathrm{P}=0.05$.

Table 4 showed that on organizational factors only the respondents' responses on whether the hospital have adequate resources $(p=0.027)$ was influenced by the number of years on the job. On interpersonal factors, number of years on the job only influenced the responses on the quality of services being offered by the hospital $(p=0.040)$. Also, on facility factors, findings showed that the number of years on the job influenced the responses on whether the record department was computerized $(\mathrm{p}=0.041)$.

\subsection{Influence of Cadre on Respondents' Perception of Implementation of TQM Factors}

Table 5. Influence of Cadre on Respondents' perception of implementation of TQM Factors.

\begin{tabular}{|c|c|c|c|c|}
\hline Variable & High & Middle & Low & p-value \\
\hline \multicolumn{5}{|l|}{ Organizational factors } \\
\hline Committed to Philosophy $(\mathrm{n}=150)$ & $9(6.0)$ & $55(36.7)$ & $86(57.3)$ & $0.000 *$ \\
\hline Conscious effort in training $(\mathrm{n}=127)$ & $11(8.7)$ & $50(39.4)$ & A $66(52.0)$ & $0.000 *$ \\
\hline Adequate hospital resources $(n=122)$ & 17 (13.9) & $52(42.6)$ & $53(43.4)$ & $0.002 *$ \\
\hline Adequate motivation of staff $(\mathrm{n}=177)$ & $32(18.1)$ & $70(39.6)$ & $75(42.4)$ & $0.002 *$ \\
\hline Staff awareness $(\mathrm{n}=181)$ & $44(24.3)$ & $66(36.5)$ & $71(39.2)$ & 0.086 \\
\hline \multicolumn{5}{|l|}{ Interpersonal factors } \\
\hline Open to suggestions \& ideas $(\mathrm{n}=137)$ & $28(20.4)$ & $57(41.6)$ & $52(38.0)$ & 0.355 \\
\hline The quality of personnel is $(n=111)$ & $16(14.4)$ & $50(45.0)$ & $45(40.5)$ & $0.014^{*}$ \\
\hline Sufficient supervision of staff $(n=130)$ & $26(20.0)$ & $55(42.3)$ & $49(37.7)$ & 0.348 \\
\hline A feedback mechanism in place $(n=152)$ & $30(19.7)$ & $66(43.4)$ & $56(36.8)$ & 0.247 \\
\hline Poor services $(\mathrm{n}=173)$ & $48(27.7)$ & $59(34.1)$ & $66(38.2)$ & $0.019^{*}$ \\
\hline \multicolumn{5}{|l|}{ Facility factors } \\
\hline State of the art equipment $(n=82)$ & $17(20.7)$ & $36(43.0)$ & $29(35.4)$ & 0.716 \\
\hline Hospital facilities can support the practice of TQM $(n=98)$ & $16(16.3)$ & $44(44.9)$ & $38(38.8)$ & 0.104 \\
\hline The record department is computerized $(\mathrm{n}=134)$ & $34(25.4)$ & $56(41.8)$ & $44(32.8)$ & 0.857 \\
\hline All the lab services are functional $(n=150)$ & $39(26.0)$ & $68(45.3)$ & $43(28.7)$ & 0.148 \\
\hline Functional diagnostic equipment @ radiology depart. $(\mathrm{n}=114)$ & $18(15.8)$ & $49(43.0)$ & $47(41.2)$ & $0.027 *$ \\
\hline
\end{tabular}

Statistically Significant $=* \mathrm{p}=0.05$.

Table 5 showed that the respondents cadre had influence on their responses to all the organizational factors with exception of staff awareness of the concept $(p=0.086)$. On interpersonal factors, findings showed that cadre had influence on the quality of personnel in the hospital $(\mathrm{p}=$ $0.014)$ and quality of services offered $(p=0.019)$. Also, on facility factors, the result showed that cadre had influence only on functional diagnostic equipment being available ( $\mathrm{p}=$ 0.027).

\subsection{Focus Group Discussion (FGD)}

Organizational factors.

1. Management commitment
There was a high perception among the respondents that the management was not committed to the implementation of TQM. They mentioned that there were policies in place in the hospital that can enhance proper implementation of the concept but management have not put it into use. The participants believed that the management has not shown enough leadership in the area of quality management and for the hospital to make a serious headway in the proper implementation of the concept; the management must lead by example. A participant put it succinctly:

' 'The management is just paying lip service to the issue of quality management. There has to be a change in their attitude and they must lead and the workers will then follow 
them for it to work"

2. Effort in training staff

The focal group respondents were aware that there was a policy and procedure in place to improve the staff. They observed that it is only a particular category of staff that has been benefited from it. It was noted that some of the reasons for not attending certain training programmes for improvement was because of lack of fund, difficulty in getting training days and also due to staff shortage. They however, mentioned that denied opportunity to improve was a missed opportunity to improve their ability to do their work effectively and efficiently. As one of the staff observed,

' For many years, I have been a staff of this hospital, I have not gone for any training programme and I heard that medical doctors were always going for training programmes without any problem"

3. Availability of resources

There was a unanimous agreement among the participants that the hospital have enough human and maternal resources to achieve the goals of TQM. However, the participants noted that what hospital is lacking is proper coordination. One of the participants captured the situation aptly:

'The hospital has large pool of resources that if properly harnessed can achieve whatever they want to achieve"

4. Motivation of staff

The respondents noted that lack of motivation of staff by management was one of the major reasons that the concept have not been properly embraced by in the hospital. They believed that if the staff were properly motivated, all hands will be on deck to ensure the success of the program in the hospital. As a participant said,

' 'Like me, I have been on one grade level for the past six years. Management must encourage the staff in any way possible to achieve success in this concept"

5. Awareness of the concept

The respondents were aware of the need to offer quality service to customers that patronize the hospital. However, they advocated for the setting up of a department responsible for creating awareness, monitoring and evaluating the implementation of the concept in the hospital. The participants observed that management sometimes engages external consultants to train the staff on some aspects of the concept as a result the staff did not feel that they have a stake in the whole exercise. As captured by one of the participants,

"For the concept to be sustained in this hospital, there have to be awareness creation on a continuous basis"

\subsection{Interpersonal Factors}

\section{Feedback mechanism}

The interview with the group revealed that the employees felt that there was no avenue to contribute ideas on how the hospital services should be done. Also, the participants felt that some off the staff were not willing to provide feedback to management because the environment is not conducive for it, as they were scared so as not to be victimized. A participant described it this way:

"We can only make feedback contribution if it is anonymous, but there is no structure in place"

2. Services offered to the public

Most of the staff in the FDG indicated that the services rendered to the general public were poor. They noted that there was no means of monitoring and measuring quality in the hospital. It also emanated from the group that the hospital only utilized data that indicated the number of drugs the hospital dispensed to the patients. At the time of this discussion, there was no patient's satisfaction survey in the hospital. As captured aptly by one of the participants:

'For the hospital to be in the forefront, there must be measures put in place to know how we are performing because this concept is patient centered"

3. staff Attitude to client and work

There was a consensus among the participants that it was not encouraging and they observed that maybe it is a government job but still believes that there is still room for improvement. One of the participants said,

"You know that government work is no man's business whether we work or not, our salaries will be paid"

\subsection{Facilities Factors}

All the members of the group agreed that the hospital did not have state of the art of equipment or facilities but that what is in the hospital is comparable to what is obtainable anywhere in the country. They noted that the major problem confronting the hospital os proper maintenance of existing equipment and facilities.

They also agreed that the pharmacy was well stocked with quality drugs which they usually purchased from the drug manufacturing companies and that the laboratory services and nursing services were doing a good job considering the limitations they faced every day in their operations in terms of having appropriate equipment and adequate staffing. A participant summarized it thus:

"For now we are not yet at the promised land but if everything is put in place, we will surely get there"

The group did not agree that the location of the hospital which is situated outside Enugu metropolis would have effect in the implementation of TQM in the hospital. According to them, the distance is just about $20 \mathrm{~km}$ and also that the hospital management made proper arrangement with private bus operators that commute patients and staff from Enugu metropolis daily. As captured by one of the participants:

'It was immediately after the relocation to this permanent site that the services were affected but now things have normalized"

\subsection{Environmental Factors}

It was agreed among the group that the hospital have not done well in this area. The discussion revealed that for the hospital to sustain TQM practice these environmental factors have to be institutionalized and also a department should be created to oversee it. Also, they agreed that external consultants should be engaged a times to increase the capacity of the human resource in the new department. One 
of the participants summarized it thus:

'It is very important that this programme is sustained in this hospital so that it will not fade away with time"

\subsection{Economic Factors}

There was a unanimous agreement across the FDG that the cost of accessing services in the hospital is the cheapest in the state considering the type of human resource available in the hospital and it might be attributed to the subvention they receive from the federal government of Nigeria. They mentioned that the impress that were disbursed to the departments were not adequate for the departments to actualize their set objectives. The group agreed that the impress disbursed should be adequate and also on time and a monitoring system for the usage in each department should be put in place. One of the participants had this to say:

'If not the money that comes from the government we might not be able to meet our obligations but we need to utilize the little we have very well"

\section{Discussion}

\subsection{Organizational Factors}

The findings in the study showed that greater number of respondents especially those with tertiary education did not agree that the management were committed to the philosophy of TQM in the hospital and that the management was not making effort in staff training in the hospital. Similar report was obtained from focus group respondents who mentioned that there were policies in place in the hospital to ensure proper implementation of TQM in the hospital but the management had failed to put it to maximum use. This finding supports what Breedlove et al [20], Balasubramanian and Al-Shdaifat observed, that the hospital management needs to lead the total quality process and also encourage others within the healthcare institution to follow and prove to them that management means what they say about quality $[21,22]$. Nonetheless, the findings contrasted with what Skiti reported on the average score on the manner the management have implemented the organizational mission, vision, short and long term goals [23]. Some of the factors that may militate against implementation of TQM are social complexity of certain organizations, the uncertainty of the cause-effect relationship between implementing TQM and the organizational performance as reported by $\mathrm{Li}$ et al, Barney et al, and Mosadeghrad et al [24-26]. Other issues are training and employee education; Kalsounakis, Hack and Wageman as well as employee empowerment as noted by Shortell et al and Boerstler et al [27-30].

The majority of those with tertiary education believed that resources of the hospital were not adequate; this is similar to what Barney et al reported [25]. In their study, it was revealed that management staff might understand the need for empowering staff, having a quality team, having a suggestion or feedback system and training programmes but might not implement it in the organization due to shortage of human and/or financial resources. It is also noticed that the vision statement of hospitals allows organizational members across all cadres to understand and identify hospital quality improvement methods, Kaltsounakis [31]. Fok et al reported that staff see TQM as making them work for more hours with less pay [32].

\subsection{Interpersonal Factors}

The majority of the respondents stated that the management were not open to suggestions from the staff: this might account for the reason why greater number of the respondents with tertiary education agreed that there was no feedback mechanism in place in the hospital. This finding is collaborated by Kaltsounakis that reported involvement of all organizational members in quality process thus creating a culture of quality [31]. The respondents with tertiary education believed that quality personnel were inadequate in the hospital but that the quality of services which the hospital rendered to the public was good, similar to what Chakrabusty et al and Shehu et al reported indicating that majority were satisfied with physicians' courtesy, attention to complaints, patience with them, explanation of what they wanted to know and providing them with good advice and treatment [31, 32]. There was insufficient supervision of staff in the hospital on the implementation of TQM, especially among those that had spent less than ten years in the facility, this is similar to what Anyansi [34] reported in Ebonyi state, Balasubramanian in India and Al-Shdaifat [21, 22].

\subsection{Facilities Factors}

There was lack of state-of-art equipment in the hospital. Majority believed that most of the diagnostic equipment at the radiology department were not functional and could not support the implementation of TQM. Anyansi in Ebonyi state reported that most of the respondents were not satisfied with the services offered to them at the radiology department [34, 35]. The reason for this may be due to low subvention released to the facilities as indicated by Balasubramanian and Mosadeghrad et al [21, 26]; this is in contrast to what Aghaeze et al and Min et al reported in their study [36. 37. 38]. However, the reason for this discrepancy is not known. The location of the hospital was reported not to have any effect on the implementation of TQM in the hospitals, in contrast to the findings by Whitworth in Uganda on the determinants of attendance to an eye clinic in the country which showed that fewer percentages of those referred to the district hospital attended because of the distance to the referred hospital [39].

\subsection{Environmental Factors}

The TQM standards were neither written nor communicated to the staff regularly, from the results of the FGD. This is in contrast to what Skiti [23] reported in their study in which they gave a high mean score and a low coefficient of variation in the areas of consistency in updating TQM regulations and performance of routine checks on staff 
conformity to the prescribed standards. Similarly, Min et al [38] reported that there is a need for hospitals to constantly increase their awareness and ability to serve patients and meet quality standards through regular communication to staff of the expected standards.

\subsection{Economic Factors}

Majority of the respondents reported that the subventions from the government were inadequate. The absence of a robust TQM system can result in limited funding, as reported by Min [38]. This could be explained, since out of the recommended $15 \%$ national budget allocation to health, only $5 \%$ is released. In addition, the absence of a governance structure for TQM as well as processes and extensive staff training on TQM will hinder funding and accreditation of health facilities, Min [38]. The effect of poor funding and non-accreditation felt at all the levels of health care.

\subsection{Limitation of the Study}

One major limitation to this study was the restriction of this study to only one tertiary public health institution. The responses from this study may not represent what is obtainable in the primary and secondary health institutions.

\section{Conclusion}

The study shows that the management of UNTH has not shown enough positive attitudes towards implementing the principles of TQM in the hospital resulting from poor allocation of human and material resources to its implementation. Among the different components of TQM, the interpersonal factors were considered lacking in the hospital: this creates a need for the management and staff to revisit the concepts of TQM and review its implementation practices within the hospital. This will help the management and staff to reshape their attitudes towards implementing the principle in the hospital. The equipment available at the hospital were inadequate to support the implementation of TQM in the hospital despite being comparable those provided by other tertiary hospitals in the country. However, there is a need to investigate the implementation of TQM concepts in other tertiary healthcare facilities in South East Nigeria and other geopolitical zones of the country, for similar or divergent trends. Given the perceptions of hospital staff on the implementation of TQM regarding patient care, it is equally important to investigate the patient perceptions of quality of care received from this and other tertiary health facilities. The number of study participants was relatively high, thus giving a lot of insight into the perception of TQM implementation in the tertiary hospital. For secondary and primary health care facilities which have a smaller number of personnel, there should be an exploration of the implementation of TQM in these categories of facilities. Finally, economic factors were found in this study to greatly influence the effective implementation of this principle in the hospital. Overall, the preparedness of the management to the implementation of TQM in the hospital is at the lowest level and the demographic factors examined greatly influenced the implementation. Therefore, more awareness should be created and targeted towards the management and employees of the hospital on the goals of TQM as well as the need for sustaining the programme in the hospital when implemented. It is also important that management demonstrates enough commitment in implementing TQM in the hospital and equally provide the enabling environment for the staff to participate in quality improvement activities: this can commence with training on TQM concepts, systems and implementation. It is very important that the hospital develops methods and procedures to implement these guidelines which Conclusion: make a case for further studies in secondary or primary HFs, and also in private. Make a case for studying patient perspectives as against this study which is from the health workers' perspectives should be made available to all staff and equally placed at strategic places in the hospital.

\section{References}

[1] Sivadas E, Baker - PreWitt JL. An examination of the relationship between service quality, customer satisfaction, and show loyalty. International journal of Retail and Distribution Management, (2003), 28 (2), 73-82.

[2] Yavas U, Bilgin B, Shenwell DJ. Service quality in the banking sector in an emerging economic: a consumer Survey. International Journal of Bank Marketing. (1997), 15 (6), 217 -223.

[3] AlDhaafri, H. S., Al Swidi, A. K and Yusulf, R. Z (2016). The mediating role of TQM and organizational excellence, And the moderating effect of entrepeunurial organization culture on the relationship between ERP and organizational performance. The TQM Journal, 28 (6): 991-1011.

[4] Camison C. Total Quality Management in Hospitality: An Application of the EFQM Model. Tourism Management, (1996), 17 (3), 191-201.

[5] Khalil, M., Khalil, R. and Khan, S. (2019). A study of the effect of supply chain management practices on organizational performance with the mediating role of innovations in SMEs. Uncertain Supply Chain Management, 7 92); 179 - 90.

[6] Yousset FN, Nel D, Bovaird T. Health Care quality in NHS hospitals. International Journal of Healthcare Quality Assurance. (1996), 14 (3), 104 - 110.

[7] Kashif, M., Altaf, U., Ayub, H. M., Asif, U and Walsh, C. (2014). Customer satisfaction in a public in Pakistan, PAKSERVE application. Global Business Review. 15 (4): 677-93.

[8] Lim PC, Tang NKH. The development of a model for total quality healthcare. Managing service quality. (2000), 10 (2), $103-111$.

[9] Albrecht, S. L., Bakker, A. B., Gruman, J. A., Macey, H and Saks, A. M. (2015). Employee engagement, human resources management practices and competitive advantage, an integrated approach, Journal of Organizational Effectiveness, People and Performance, 2 (1): 7-35. 
[10] Eze CU. Survey of patient satisfaction with obstetric ultrasound at University of Nigeria Teaching Hospital Enugu Nigeria. Niger J. Health Biomed. Sci. (2006), 5 (1), 93-97.

[11] Ghosh, M and Sobek II, D. K. (2015). A problem solving routine for improving hospital operations. Journal of Health Organization and Management. 29 (2): 252 - 70.

[12] Afolabi M. O, Erhun W. O. Patients' response to waiting time in an outpatient pharmacy in Nigeria. Trop J. Pharm. Res, (2003), 2 (2), $207-214$.

[13] Ofili AN, Ofovwe CE. Patients' assessment of efficiency services at a teaching hospital in a developing country Ann. Asr. Med. (2005), 4 (4), 150 - 153.

[14] Olusina AK, Ohreri JU, Olawrwura MO Patient and staff satisfaction with the quality of in-patient psychiatric care in a Nigerian General Hospital. soc. Psychiator. Psychiatr. Epidemol, (2004), 37 (6), 283 - 288.

[15] Sadeh, E. (2017). Interrelationships among quality enablers, service quality, patients' satisfaction and loyalty in hospitas. The TQM Journal, 29 (1): 101 -17.

[16] SERVICOM evaluation reports: http://www.servenigeria.com/accessed 14/10/2012.

[17] Cheng, S. Y., Bamford, D., Papalexi, M. and Dehe, B. (2015). Improving access to healthcare services-challenges in lean application. International Journal of Public Sector.

[18] Ju, K. J and Park, B. (2016). An empirical study of total quality management and its influence on nurses' attitude and service performance in healthcare organization. International Journal of Services and Operations Management. 24 (2): 147 66.

[19] Al-Hyeri, K., Abu Hammour, S., Abu Zaid, M. K. S and Haffer, M. (2016). The impact of lean bundle on hospital performance: does size matter? International Lournal of Healthcare Quality Assurance. 29 (8): 877 - 94.

[20] Breedlove TH. Measuring the impact of quality improvement efforts. Health care - financial management (1994), 4 (9), 32 34.

[21] Balasubramanian M. Total Quality Management [TQM] in the Healthcare Industry - Challenges, Barriers and Implementation Developing a Framework for TQM Implementation in a Healthcare Setup. Science Journal of Public Health. (2016), 4 (4), 271-278.

[22] Al-Shdaifat E. A. Implementation of total quality management in hospitals. Journal of Taibah University Medical Sciences. (2015), 10 (4), 461-466.

[23] Skiti V. Barriers in implementing Total Quality Management in Kraaifontein Public health care facility in the western cape, Stellenbosch University, (2009).

[24] Li C. and Sweetman G. A healthcare quality management system underpinning the 3-E model and its application in a new tertiary hospital in Australia. International Journal of Nursing Sciences. (2517), 4: 112 - 116.

[25] Barney J, Barney P. Firm Resources and sustained competitive advantage. Journal of management, (2011), 82: $30-3$.
[26] Mosadeghrad, A. M. \& Ferlie, E., Total Quality Management in Healthcare in Ortenblad, A. Abrahamson Lofstrom, C. \& Sheaff, R., Management innovations for healthcare organizations: adopt, abandon or adapt? (2016) Routledge.

[27] Kaltsounakis Z. Implementing Total Quality Management in Canadian health care: An empirical investigation. Unpublished Master's thesis, concord University, Montreal, (2010).

[28] Hack R, Wageman R. Total quality management: Empirical, conceptual and practical issues. Administrative Science Quarterly. (1995), 40; $309-342$.

[29] Shortell SM, Levin DZ, O'Brien, JL. Assessing the evidence on CQI: Is the glass half empty or half full. Hospital Health Service Adm. (1995); 40: 4-24.

[30] Boerstler H, Foster RW, O'Connor ES. Implementation of total quality management: conventional wisdom versus reality. Hospital Health Services Admin. (1996), 41: 143 - 159.

[31] Fok LY, Hertman SJ, Patti AL, Rasek JR. Human factors affecting the acceptance of total quality management. International journal of quality and reliable management. (2000), 17 (7), $714-729$.

[32] Chakrabusty G, Grasth G, Gunningham M. Understanding consmers' preferences for dental service. Journal of Healthcare Market. (1993), 13: 16-22.

[33] Shehu CD. Importance of Total Quality Management on Hospital Management. An MBA Seminar presentation to the Dept. of Business Administration University of Maiduguri, (2012).

[34] Anyansi TC. (2011) Technique for managing quality and health services administration of Ebonyi State Teaching Hospital Abakaliki. An MBA Research project work of ESUT Business School.

[35] Aghaeze EO. Total Quality Management in selected Government Hospitals in Enugu State. (2010). An unpublished $\mathrm{Ph}$. D Research proposal of University of Nigeria Enugu Campus, (2012).

[36] Supplying Principles and Practices - October 1, 2018 - USPS. com. Sourced at https://about.usps.com/manuals/spp/spp.pdf. Accessed on 22nd May 2019.

[37] OPINION: AN OVERVIEW OF SERVICE DELIVERY INITIATIVE: 12 YEARS AFTER. Sourced at: https://thewillnigeria.com/news/opinion-an-overview-ofservice-delivery-initiative-12-years-after/ accessed on: $23^{\text {rd }}$ may 2019.

[38] Min L., Douglas B. L., Cheng-Yu H., Xiang-Chan L., YingChu Z., Xing-Hua W. et al. Evaluating patients' perception of service quality at hospitals in nine Chinese cities by use of the ServQual scale. Asian Pac J Trop Biomed. (2015); 5 (6): $497-$ 504.

[39] Whitworth J. Pickering H, Mulwanji F, Ruberantwari A, Dolin P, Johnson G. Determinants of attendance and patient satisfaction of eye clinics in South Western Ugandan. Health Policy Plan. 1999; 1477-81. 